\title{
Deferred Taxes Revisited
}

Ron Colley, (Email: rcolley@ westga.edu), State University of West Georgia Joseph Rue, (Email: jrue@ fgcu.edu), Florida Gulf Coast University

Ara Volkan, (Email: avolkan@westga.edu), State University of West Georgia

\begin{abstract}
The study examines the deferred tax accounting theory and procedures required by the FASB in the context of the unit problem. The unit problem involves the selection of the appropriate perspective (either individual or aggregate) for applying measurement and recognition conventions to phenomena of interest. From an individual event perspective, the FASB's conclusions regarding liability recognition are inconsistent with the definition of liabilities found in the Statement of Financial Accounting Concepts No. 6. In addition, the use of inconsistent perspectives by S109 creates disagreements with the FASB's position, where both the individual and aggregate perspectives are used simultaneously as the basis of the FASB's decisions. The study argues that the income tax accounting issue should be viewed from an aggregate perspective and concludes that the flow-through method of accounting for income taxes should be adopted. The impact of eliminating deferred taxes and adjusting the liability and stockholders equity balances on the debt-to-equity (DTE) ratio is computed for the entire COMPUSTAT database (20 years). For the 817 firms that persist throughout the 20-year period, each year, the net deferred tax balance for each company is compared to the balance in the previous year, with increases $(53 \%)$ outnumbering decreases (32\%), and the remainder (15\%) showing no change. In addition, the average annual net deferred tax balances of entire sample show increases for the 15 of the 20 years examined and the balances for persisting firms show increases for 17 of the 20 years examined. Finally, the relative size of the net deferred tax balances as a percentage of total assets and total liabilities for both the overall sample and the persisting firms range from $4.1 \%$ to $5.8 \%$ of total assets and from $7.9 \%$ to $11.8 \%$ of total liabilities. Statistical results show that the decreases in the DTE ratio are significant for each year, with an overall average decrease of 19\%. Thus, the flow-through method results in significant changes in a key ratio that is used in the financial evaluation of most companies. Conversely, the DTE ratios currently used in the financial evaluation of companies are flawed because the net deferred tax balances are included in liabilities, when it is clear that these accounts do not meet the liability criteria specified in accounting theory.
\end{abstract}

\section{Introduction}

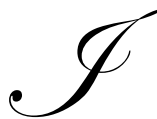

n February 1992, the Financial Accounting Standards Board (FASB) issued Statement 109 (S109) to bring closure to accounting and financial reporting controversies concerning deferred taxes (FASB, 1992). S109 required companies to use the comprehensive inter-period tax allocation method for all timing differences between income tax reporting on the financial statements and on the tax returns. The companies were required to use the asset/liability approach and the current tax rate to accumulate the deferred tax assets and liabilities that resulted when the financial accounting and tax accounting bases of their assets and liabilities diverged. For income statement reporting, the legal tax liability for the period was adjusted by the periodic changes in the deferred tax asset and liability balances, to arrive at the tax provision (tax expense). S109 further required that an allowance account be established if it were more likely than not that the deferred tax assets would not be realized. Finally, there were fairly complex rules concerning the treatment of loss carry-forwards, tax planning strategies and their use in determining the balance in the allowance account, classification of the asset and liability balances in the balance sheet, tax rate and status changes, business combinations, and disclosures in the footnotes. 
The FASB issued S109, which replaced S96 (FASB, 1987), after much debate and a considerable amount of compromise. S96 was to take effect after December 15, 1988. However, due to the complexities of implementing S96, the FASB delayed its effective date three times (e.g., FASB, 1991). Thus, since its inception, the FASB has struggled with the controversy of changing the reporting requirements for deferred taxes promulgated in Accounting Principles Board (APB) Opinion \#11 (AICPA, 1967). The large number of responses received by the FASB throughout the standard formulation process, the continuing controversies regarding the final pronouncement, and the delays in implementing the standards attest to the complexity and controversy of the issue.

\section{Purpose}

This paper examines the theory underlying the current accounting and reporting standards for deferred taxes within the context of the unit problem and argues for an alternative view. In addition, the behavior of deferred tax balances over two decades is observed. Next, the impact of eliminating deferred taxes and adjusting the liability and stockholders equity balances on the debt-to-equity (DTE) ratio is computed. The financial consequences of the flow-through approach advocated in the paper are examined for the entire COMPUSTAT database (20 years).

\section{Background}

Since the release of S96 and S109, critics have raised several concerns about accounting for deferred taxes. They have criticized: (1) the inconsistent treatment of the deferred tax asset and liability (Wolk, Martin, and Nichols, 1989; Parks, 1988); (2) the FASB's failure to allow for discounting of the deferred tax liability (Rayburn, 1987); (3) the method's complexity and potential lack of usefulness (Burton and Sack, 1989; Gregory, Petree, and Vitray, 1992); and (4) the FASB's failure to deal with temporary differences that are permanently deferred (Jeter and Chancy, 1988). Many of these concerns have not been fully addressed in either statement.

The controversy over the accounting for income taxes will not subside until the FASB completely reconsiders its position and adequately addresses the unit problem (Devine, 1985). The unit problem involves the selection of the appropriate perspective for applying measurement and recognition conventions to the phenomenon of interest. The perspective ranges from accounting for individual events or transactions to accounting for aggregate events or transactions. The positions taken by both proponents and opponents of S96 and S109 are affected by whether one views income tax accounting as an issue of accounting for individual events or as an issue of accounting for aggregate activity. The positions one takes regarding the income tax accounting issue are directly related to one's view of the unit.

\section{The Unit Problem}

The unit problem addresses the selection of appropriate attributes for characterizing the event for which one wishes to account. The accounting process involves the identification, grouping and measurement of what are believed to be relatively homogeneous events. If events are not strictly homogeneous, however, a problem can arise in selecting attributes of the group or class portrayed by the accounting process.

Some may take a specific or individual perspective that examines the attributes of one member of the group and assumes that those attributes may be generalized to the other members. Others may take an aggregate perspective that attempts to identify attributes relevant to the accounting process by examining the behavior of the group taken as a whole rather than focusing on individual members. Given some nontrivial degree of heterogeneity within the group, an observer adopting the individual perspective will most likely identify a different set of accounting attributes for the class of events than someone who takes an aggregate perspective. Thus, supportable alternative perspectives (individual versus aggregate) can emerge which will lead to different positions on the relevant attributes of an accounting phenomenon and to different conclusions concerning its accounting disposition.

For example, warranty obligations qualify as a liability only from an aggregate perspective. It is unlikely that a warranty obligation will arise from a given sales transaction (individual perspective), since the probability that a particular product is defective is small. However, experience with aggregate sales and related warranties suggests 
that some sales will require warranty claims. Thus, the existence of a warranty obligation makes sense only when the evaluation is made from an aggregate perspective. This example is applicable to many other financial statement items as well.

\section{S96 \& S109 - An Individual Event Perspective}

While not explicitly stated, the FASB's view of the income tax accounting issue generally requires that an individual event perspective be taken within the context of the unit problem. The FASB's position is that tax consequences of an individual event are separable from aggregate taxable income (FASB, 1987, par. 174). S109 indicates that individual temporary differences become taxable or deductible when the related asset is recovered or the related liability is settled (FASB, 1992, Summary). While the first step in the procedures outlined for implementing S109 requires the analysis of individual temporary differences, these differences are later summarized to determine the net taxable amounts upon which the liability calculation is based.

The FASB's discussion of the basis for their conclusions also clearly indicates the individual event perspective that they take. For example, in response to advocates of partial allocation (an aggregate perspective), the FASB states that the deferred tax consequences of a depreciation difference for a particular depreciable asset ordinarily will result in a sacrifice in future years (FASB, 1987, par.179). There will be a future sacrifice because a new individual difference resulting in a taxable amount will be used up to offset an old, reversing taxable amount.

Based upon this individual event perspective, both standards required the adoption of the asset-liability approach of accounting for inter-period income tax allocation. This method is built upon the premises that deferred tax assets and liabilities will result in future tax obligations or benefits irrespective of assumptions concerning future taxable income or loss and that the objective of accounting for income taxes is to recognize both current and deferred taxes payable or refundable at the date of financial statements as a result of all events recognized in the financial statements and by provisions of existing tax laws. This line of reasoning assumes that the tax consequences of earning income or incurring losses or expenses in future years are not anticipated for purposes of recognition and measurement of a deferred tax liability or asset. Since this view is not defensible in many situations, S109 modifies this requirement in case of deferred tax assets by considering future events to assess the likelihood that future tax consequences have been affected by events recognized in the current financial statements (FASB, 1992, par. 6).

\section{Allocation Versus Non-Allocation - Theoretical Issues}

\section{Taxes - Expenses or Redistribution of Wealth?}

Deferred tax accounting is based on the concept that income taxes are expenses. We contend that the question of whether to allocate taxes between periods depends on whether the income tax provision for a period is an expense or simply a redistribution of wealth. Although it could be argued that the expenses can be allocated, income distributions should not be allocated among periods. Income distributions should be charged to the period in which they occur. In other words, the tax provision should equal the taxes payable if taxes are income distributions.

Thus, the deferred tax debate can be settled by first answering one fundamental question: are deferred taxes a consequence of the act of taxation which is a transaction occurring between the entity and the public sector or a consequence of purchasing and selling individual assets, incurring specific liabilities and expenses, and other activities of the entity? The answer to this question must be determined independent of the questions concerning the recognition and measurement of deferred taxes.

If taxation is redistribution of wealth, then business should only be concerned with recognizing income taxes in the period where the related taxable income occurs. Taxes are a function of government fiscal and monetary policies, and they are not functionally related to financial reporting of companies. While we believe that they represent redistribution of wealth, in the remainder of this paper we will yield to the prevailing theory that recognizes taxes as expenses. 


\section{Challenging the Myth of Inter-Period Allocation}

Even when one agrees that taxes are expenses of doing business, one can maintain that the amount of income tax expense reported on a company's income statement should be the same as the income taxes payable for the accounting period as determined by the income tax return. Under this approach, no inter-period allocation of income taxes is necessary. Schroeder, Clark, and Cathey (2001, pp. 358-359) summarize the arguments advanced by both the advocates and opponents of allocation into several categories: 1) the nature of expenses and liabilities, 2) the unit perspective to be applied to recognition and measurement, and 3) assessment of future cash flows.

Non-allocation advocates take positions that address issues embedded in all three categories. First, they contend that income taxes result only from taxable income. Whether or not the company has accounting income is irrelevant and matching income taxes with accounting income does not provide relevant information. The allocation of income taxes in a manner similar to other expenses is not relevant. While expenses measure the cost of generating revenue, income taxes generate no revenues. They are neither incurred in anticipation of future benefits nor are they expirations of costs.

Next, non-allocation advocates point out that income taxes are not levied on individual items of revenue and expense. Therefore, there can be no temporary differences related to these items. In addition, inter-period tax allocation hides an economic difference between a company that employs tax strategies that reduce current tax payments and one that does not. Reporting a company's income tax expense at the amount paid or currently payable should provide more useful information in predicting a company's future cash outflows.

Finally, those who favor non-allocation argue that income tax allocation entails a forecast of future profits. To incorporate such forecasts into accounting measures is inconsistent with the principles of accounting. There is no present obligation for the potential or future tax consequences of past transactions because there is no contract (as it is the case with employee benefits and leases) and no legal liability to pay taxes until an actual tax return is prepared. Moreover, the accounting processes required by S109 are too costly for the purported benefits.

Inter-period tax allocation advocates also address similar issues, but arrive at conclusions that are completely opposite to those of non-allocation advocates:

- $\quad$ Since taxes result from the incurrence of transactions and events, tax expense should be based on the results of the transactions or events that are included in financial statements.

- Income taxes are an expense of doing business and should involve the same accrual, deferral, and estimation concepts that are applied to other expenses.

- $\quad$ Differences between the timing of individual revenues and expenses do result in temporary differences that will reverse in the future.

- Inter-period tax allocation makes a company's net income a more useful measure of its long-term earning power and avoids periodic income distortions resulting from tax regulations.

- Non-allocation of a company's income tax expense hinders the prediction of its future cash flows. For instance, a company's future cash inflows from installment sales collection would usually be offset by related cash outflows for taxes.

- A company is a going concern, and income taxes resulting from individual events that are currently deferred will eventually be paid.

- $\quad$ Temporary differences are associated with future tax consequences. Reversals of originating differences that provide present tax savings will result in future taxable incomes and tax payments. Thus, deferred tax liabilities are similar to other contingent liabilities.

In the following sections we will challenge the arguments presented by the advocates of inter-period tax allocation. While arguments $1,3,5$, and 7 can be challenged under the unit problem, arguments 2 and 6 will be countered using the definitions of liabilities and expenses in FASB's concept statements. Finally, argument 4 is a typical strategy used by those who don't want change in the existing procedures of accounting in a given area, such as stock options, employee benefits, and derivatives. The discussion which follows addresses the issues concerning 
the unit perspective, the definition of assets and liabilities, the usefulness of deferred taxes for decision-making, and the conclusions reached by the FASB concerning deferred taxes.

\section{The Question of Asset-Liability Recognition}

While the arguments presented in this section also apply to deferred tax assets, for the sake of brevity we address only the liability issue. In the FASB's view, the deferred tax liability meets the Statement of Financial Accounting Concepts No. 6 (SFAC 6) definition of a liability that is the probable future sacrifice of economic benefits that arise from present obligations of a particular entity to transfer assets or provide services to other entities in the future as a result of past transactions or events (FASB, 1985, par. 35). In support of its conclusions in S109, the FASB argues that:

- $\quad$ Temporary differences will become taxable amounts in future years as a result of events whose occurrence is already inherently assumed in an enterprise's statement of financial position for the current year,

- $\quad$ No other future events need occur,

- $\quad$ The enterprise might be able to delay settlement of a tax obligation by delaying the events that give rise to taxable amounts. However, a contention that those events will never occur would contradict assumptions inherent in the statement of financial position, and

- $\quad$ Tax obligations are incurred when temporary differences originate.

It can be demonstrated that this conclusion is not supported by the FASB's implicit individual event perspective. If one takes an individual event perspective, the characteristics of a liability resulting from depreciating an individual asset using different depreciation methods are present only if the temporary differences between taxable income and financial statement income that result in future net taxable amounts can be recovered through the use of sufficient future taxable income. However, these timing differences may reverse when the firm has no taxable income or incurred a loss. Since taxes are not paid, there is no future economic sacrifice.

Thus, from an individual event perspective, the resource transfer is dependent upon future events, namely future income. Further, the sacrifices of economic benefits arising from present obligations of an entity disappear or are significantly reduced if a depreciable asset is sold during its useful life for an amount less than its book value. Liability recognition is warranted only if the asset is held to the end of its useful life. Liability recognition resulting from an individual transaction depends upon aggregate future events, that is, future operational decisions regarding depreciable assets.

Another question is whether a present obligation exists. Unlike all other liabilities recognized for financial reporting purposes, there is no explicit or implicit contract between the reporting entity and the creditor. At any point in time in the life of the entity, the government does not have a claim to the entity's assets for the deferred tax liability. The only time the claim arises is in the future when sufficient taxable income is reported. While the recovery of the asset through use or sale has a high probability of occurrence in a going concern, the incidence of tax depends on the occurrence of future events that together determine whether taxable income exists.

The third aspect of the SFAC 6 definition is that future sacrifices are a result of past transactions or events. While depreciation is described as an internal event (FASB, 1992, par. 138), temporary differences between taxable income and financial statement income are not caused by the event of depreciation. The differences occur because of the use of alternative methods of depreciation. Since the law allows alternative allocation schemes, the resulting taxable income and accounting income are caused by different allocation methods and estimates of residual value. They are not the result of past transaction or events since estimates of useful life and residual values must reflect future usefulness.

Finally, the long-term deferred tax liability is the only non-current liability that is exempt from discounting, violating the FASB standards and concepts related to the measurement of liabilities and the requirements to use present values. S109 (par. 199) essentially declines to address this issue. If the trends in the size and nature of deferred tax balances were examined to determine appropriate discount periods, the process of discounting could 
reduce the reported deferred tax amounts to zero or to a very small number. One of the arguments against the use of discounting is that since the government does not recognize the existence of a liability and there are no other contractual counter-parties, the discount rate is zero (Rayburn, 1987). However, this argument serves just the opposite of its intended purpose, strengthening our contention that flow-through approach should be used in accounting for taxes.

\section{The Growth of Net Deferred Tax Liability Balances - An Aggregate View}

The following example illustrates how the growth in deferred tax liability supports the aggregate events perspective. Assume that a company acquires a machine with a residual value of $\$ 80,000$, a useful life of 5 years, and a cost of $\$ 1,000,000$, every year. In addition, the company uses double declining balance depreciation for tax purposes and straight-line depreciation for financial reporting. The tax rate is $34 \%$. The effect of these assumptions on the deferred tax liability is illustrated in Table 1.

Table 1 shows that the liability reaches a constant level after five years. The resulting tax liability will not be paid unless the company fails to replace a machine as it is worn out. On the other hand, the deferred tax liability is likely to increase as the company expands and adds more machines. Further, if it is assumed that the firm is holding its productive capacity stable, it will continue to acquire new machines. These additional machines will probably cost more and lead to an increased deferred tax liability. The liability is reduced only if the firm discontinues its capital investment in new machinery and starts to curtail operations. However, there are very few industries where such an outcome is probable at the aggregate level.

Any individual difference between the accounting rules used for tax purposes and those used for book purposes will follow a reversing process. If, however, several accounting phenomena are simultaneously creating tax deferrals, the nature of the aggregate deferral would not necessarily correspond to that exhibited by an individual difference. In the past, examinations of the financial statements of many companies revealed that the deferred tax positions were either stable or growing over time (Jeter and Chaney, 1988; Magee, 1984, Ch. 4). This suggests that processes such as those described in the above example exist for many firms. To the extent that this is so, the accounting profession is faced with a dilemma.

Table 1 - Illustration of Growth in Aggregate Deferred Tax Liability

\begin{tabular}{lccccc}
\hline & Year 1 & Year 2 & Year 3 & Year 4 & Year 5 \\
Increase Due to Purchase in Current Year (t) & 73.4 & 73.4 & 73.4 & 73.4 & 73.4 \\
Increase Due to Purchase in Prior Year (t-1) & & 9.0 & 19.0 & 19.0 & 19.0 \\
Decrease Due to Reversal From Year (t-2) & & & $(13.6)$ & $(13.6)$ & $(13.6)$ \\
Decrease Due to Reversal From Year (t-3) & & & & $(33.2)$ & $(33.2)$ \\
Decrease Due to Reversal From Year (t-4) & 73.4 & 92.4 & 78.8 & 45.6 & $(45.6)$ \\
Total Increase & 73.4 & 165.8 & 244.6 & 290.2 & -- \\
Liability Balance & & & & & \\
\hline
\end{tabular}

As discussed previously, a liability is defined as a situation requiring future sacrifice of assets resulting from an unavoidable obligation. If one considers the deferred tax process as resulting from an individual difference, the deferred tax liability declines in those years where the tax payment exceeds the tax expense. Then, an argument can be made, as the FASB has, that the deferred tax liability represents a future sacrifice of assets. However, as it is demonstrated above, liability recognition for individual differences is dependent upon future occurrence of aggregate income or loss, which clearly violates one of the criteria for liability recognition.

If, on the other hand, one views the deferred tax process from an aggregate perspective, considering the joint effects of many differences, the deferred asset or liability balances may remain on the company's balance sheet 
indefinitely. Although the item may represent a future sacrifice of assets, the sacrifice will be avoided indefinitely if the company continues to act in ways that maintain the aforementioned equilibrium. Accordingly, many deferred tax items do not satisfy the liability definition if viewed in the aggregate.

\section{The Choice of an Accounting Perspective - The Unit Problem Revisited}

The discussion presented above indicates that the choice of perspective from which to evaluate accounting phenomena should be based on our understanding of their underlying nature. If the phenomena are seen as members of a group where each member's range of potential behavior has impact only to the extent that it contributes to the behavior of the group, then the aggregate perspective is suggested. Alternatively, if this range of potential is fully realizable for each phenomenon under normal conditions, then an individual perspective is suggested.

The act of taxation is an aggregate phenomenon and the tax to be paid in a period is based on taxable income. Individual transactions or events are not taxed. Only aggregate financial results lead to a transfer of funds to various governments. Recognizing tax expenses, assets, and liabilities on individual events is not representationally faithful. The FASB has acknowledged the aggregate nature of income tax determination by allowing companies to utilize tax-planning strategies when considering the future years' effects of temporary differences. Thus, the FASB recognized that one objective of corporate tax policies is to minimize the annual tax obligations and that it is possible that all or a portion of a deferred tax obligation will not be paid.

Some critics of S96 and S109 advocate partial allocation, adopting an aggregate perspective. The partial allocation method recognizes that several temporary differences net out over time and never reverse (the permanent deferral) and do not require asset/liability recognition for those items. However, this method also recognizes that for a small number of unique temporary differences an individual event perspective is required. These temporary differences are deemed likely to reverse and, assuming that future taxable income will be available, a liability or asset is recognized.

The adoption of partial allocation is not appropriate for two reasons. First, the income tax is based on the aggregate taxable income of the enterprise. Therefore, mixing individual and aggregate perspectives in arriving at the appropriate accounting is inconsistent. Second, the assertion that temporary differences cannot result in liabilities without presuming future taxable income also applies to the temporary differences that are likely to reverse.

Since the FASB's deferred tax requirements cannot be supported from either an individual event perspective or from an aggregate perspective, the FASB should abandon the asset/liability method of accounting for income taxes. Therefore, tax payable indicates the amount of tax expense, and an aggregate perspective is used to properly account for corporate income taxes. If the potential effect of timing differences currently reported needs to be disclosed, retained earnings balances equal to the net deferred tax position could be appropriated and other details could be shown in the footnotes.

\section{The Impact of Implementing the Flow-Through Method}

\section{Methodology}

If net deferred tax positions were no longer reported on the balance sheet, and the flow-through method of accounting for income taxes was used, what impact would it have on a company's financial position? To answer this question, we study companies reporting a deferred tax position over two decades, from 1983 to 2002. We observe the trends in deferred tax balances for the 10,363 firms reporting these accounts in the CS Active data set in the COMPUSTAT database. Next, we select a sample of persisting firms using the 1983 data set by focusing on only those 817 companies that reported numerical information each year of the $1983-2002$ period. The COMPUSTAT variable used is TXDB, representing the net accumulated tax deferrals on the balance sheet due to timing differences between the reporting of revenues and expenses for financial reporting and tax purposes, including the effects of investment tax credits. Since this variable is not available for banks, these firms are excluded from our analysis. 
Our study focuses on the change in the debt-to-equity (DTE) ratio assuming that net deferred tax assets and liabilities are not reported on the balance sheet. Of course, many financial ratios are affected if the flow-through method is used, but the DTE ratio is a significant measure of a company's financial position. The DTE is a primary determinant of risk, and indicates the ability of a company to access capital markets.

The first step in our study is to adjust the balance sheets of companies by eliminating the net deferred tax position, represented by the COMPUSTAT data item TXDB that sums all deferred tax asset and liability amounts reported in the balance sheet. The analysis of the database shows that all net deferred tax positions have credit balances. We deduct the TXDB from total liabilities and add it to owners' equity because if the deferred taxes had not been recorded, cumulative income from previous years would have been higher. Next, we determine the DTE ratio under the current method (DED) and the flow-through method advocated in this paper (DEF) for each company. Each year, the highest $1 \%$ and the lowest $1 \%$ DTE ratios are eliminated to remove outliers.

Once the DED and DEF ratios have been computed for each company for each year, we observe the yearto-year trend/behavior of the net deferred tax position for each firm in the database and on the sample average for each year. Our expectation is that, in general, the net deferred tax liability positions for each firm and, on the average, for all firms for each year, will increase over time. Companies with negative total equity in a given year are excluded from the analyses carried out in that year.

Then the statistical analysis is carried out at two levels: all observations for the entire sample in each year and for 817 persisting firms in each year. We tested for differences of means in this study to determine significance. The test statistic is the ratio of the difference of the means of the DTE ratios to the standard error. The one-tailed ttest is used since we expect the DTE ratio to decline.

Results

While Table 2 presents the results of our study for the 1983-2002 period based on the entire sample, Table 3 presents our results for a group of 817 companies that persisted throughout the study period. The number of companies included in the analysis ranged from a low of 1,354 in 1983 to a high of 2,690 in year 2000. For the 817 companies that persisted throughout the study period, each year, we compared the net deferred tax balance for each company to the balance in the previous year, to obtain an indication of the increasing, decreasing, and stable balances. Table 4 shows that, each year, the increases outnumbered the decreases and the average increase over the period exceeded the average decrease $52 \%$ to $35 \%$. In addition, the average annual net deferred tax balances increased for 15 of the 20 years examined for the overall sample and for 17 of the 20 years for the 817 persisting firms. On the other hand, the net deferred tax balances, as a percent of total assets and total liabilities, on the average, remained stable (as demonstrated in Table 1) over the study period for both the overall sample and the persisting firms at approximately $4.9 \%$ and $9.7 \%$, respectively. An examination of the trends in these relative percentages shows that they fluctuate with the economic cycles.

While the average DED ratio for the overall sample for the 1983-2002 period ranges from a low of 1.4 in 1983 to a high of 2.8 in 2002, the average DEF ranges from a low of 1.1 in 1983 to a high of 1.9 in 2002. The ranges for the DED and DEF ratios and for the ratios of net deferred tax balances to total assets and total liabilities in the sample of persisting firms are slightly higher than their counterparts in the overall sample because in the sample of persisting firms, we take away, at least in part, the moderating influence of the portfolio effect that exists in the overall sample, with new firms entering and existing firms leaving the sample each year. In addition, the statistical tests show that the decreases in the DTE ratio are statistically significant for each year at the 99.9 percentile or better.

Thus, the implementation of the flow-through method will result in significant changes in a key ratio that is used in the financial evaluation of most companies. Conversely, the debt-to-equity ratios used at present in the financial evaluation of companies are flawed because the net deferred tax balances are included in liabilities, when it is clear that these accounts do not meet the liability criteria specified in accounting theory. 
Table 2 - Total Sample Characteristics and Results

\begin{tabular}{|c|c|c|c|c|c|c|c|c|c|c|}
\hline $\begin{array}{l}\text { (1) } \\
\text { Year }\end{array}$ & $\begin{array}{c}(2) \\
\text { Count }\end{array}$ & $\begin{array}{l}\text { (3) } \\
\text { Count } \\
\% \text { of } \\
\text { Total }\end{array}$ & $\begin{array}{l}\text { (4) } \\
\text { Avg } \\
\text { DT }\end{array}$ & $\begin{array}{l}\text { (5) } \\
\text { Avg } \\
\text { TL }\end{array}$ & $\begin{array}{l}\text { (6) } \\
\text { Avg } \\
\text { SE }\end{array}$ & $\begin{array}{c}\text { (7) } \\
\text { Uwt } \\
\text { Avg } \\
\text { DED }\end{array}$ & $\begin{array}{l}(8) \\
\text { Uwt } \\
\text { Avg } \\
\text { DEF }\end{array}$ & $\begin{array}{c}\text { (9) } \\
\text { Uwt } \\
\text { Avg } \\
\% \text { Decrease } \\
\text { In DTE }(*) \\
\end{array}$ & $\begin{array}{l}\text { (10) } \\
\text { Uwt } \\
\text { Avg } \\
\text { \% of DT } \\
\text { to TA }\end{array}$ & $\begin{array}{l}\text { (11) } \\
\text { Uwt } \\
\text { Avg } \\
\% \text { of DT } \\
\text { to TL }\end{array}$ \\
\hline 2002 & 2,254 & 21.8 & 278 & 4,990 & 1,454 & 2.8 & 1.9 & 19.4 & 4.7 & 9.7 \\
\hline 2001 & 2,512 & 24.2 & 318 & 5,596 & 1,983 & 2.3 & 1.8 & 18.4 & 4.6 & 9.1 \\
\hline 2000 & 2,690 & 26.0 & 280 & 4,599 & 1,839 & 2.2 & 1.8 & 18.0 & 4.4 & 8.8 \\
\hline 1999 & 2,614 & 25.2 & 249 & 3,753 & 1,557 & 2.0 & 1.6 & 17.0 & 4.3 & 8.5 \\
\hline 1998 & 2,504 & 24.2 & 200 & 3,168 & 1,252 & 2.0 & 1.6 & 16.5 & 4.1 & 8.3 \\
\hline 1997 & 2,416 & 23.3 & 185 & 2,740 & 1,078 & 1.9 & 1.5 & 16.8 & 4.2 & 8.7 \\
\hline 1996 & 2,355 & 22.7 & 176 & 2,854 & 1,033 & 1.9 & 1.5 & 16.8 & 4.3 & 8.8 \\
\hline 1995 & 2,207 & 21.3 & 170 & 2,324 & 973 & 1.9 & 1.5 & 17.0 & 4.4 & 8.9 \\
\hline 1994 & 2,007 & 19.4 & 173 & 2,124 & 966 & 1.8 & 1.4 & 17.6 & 4.6 & 9.2 \\
\hline 1993 & 1,899 & 18.3 & 178 & 2,211 & 945 & 1.8 & 1.4 & 18.3 & 4.8 & 9.6 \\
\hline 1992 & 1,782 & 17.2 & 162 & 2,067 & 907 & 1.9 & 1.5 & 18.5 & 4.8 & 9.5 \\
\hline 1991 & 1,713 & 16.5 & 168 & 2,067 & 962 & 1.9 & 1.5 & 18.9 & 4.9 & 9.6 \\
\hline 1990 & 1,670 & 16.1 & 179 & 2,154 & 954 & 2.1 & 1.7 & 19.6 & 5.1 & 9.9 \\
\hline 1989 & 1,631 & 15.7 & 175 & 1,917 & 888 & 2.0 & 1.6 & 19.9 & 5.2 & 10.3 \\
\hline 1988 & 1,612 & 15.6 & 165 & 1,736 & 837 & 1.9 & 1.5 & 20.1 & 5.3 & 10.6 \\
\hline 1987 & 1,595 & 15.4 & 163 & 1,500 & 783 & 1.7 & 1.4 & 20.5 & 5.5 & 11.2 \\
\hline 1986 & 1,561 & 15.1 & 149 & 1,326 & 724 & 1.8 & 1.4 & 20.5 & 5.4 & 11.2 \\
\hline 1985 & 1,471 & 14.2 & 145 & 1,175 & 733 & 1.5 & 1.2 & 20.5 & 5.5 & 11.5 \\
\hline 1984 & 1,400 & 13.5 & 131 & 1,121 & 701 & 1.5 & 1.2 & 19.7 & 5.3 & 11.1 \\
\hline 1983 & 1,354 & 13.1 & 125 & 1,003 & 687 & 1.4 & 1.1 & 19.1 & 5.1 & 10.8 \\
\hline $\begin{array}{l}\text { DT - } \\
\text { TL - } \\
\text { SE - } \\
\text { Uwt }\end{array}$ & $\begin{array}{l}\text { et deferr } \\
\text { tal liabi } \\
\text { ockhold } \\
\text { g- Unn }\end{array}$ & $\begin{array}{l}\text { tax bala } \\
\text { es } \\
\text { equity } \\
\text { ghted A }\end{array}$ & & & & \multicolumn{5}{|c|}{$\begin{array}{l}\text { DED - Debt to equity ratio under current method } \\
\text { DEF - Debt to equity ratio under flow-through method } \\
\text { DTE - Debt to equity ratio } \\
\text { TA - Total assets } \\
\text { (*) All decreases are statistically significant with } p<.001\end{array}$} \\
\hline
\end{tabular}

\section{Conclusion - No More Deferred Taxes}

The current reporting requirements for deferred taxes are too complex and costly to apply. Also, the everincreasing net deferred tax liability position for many firms does not appear to be reversing, and questions concerning whether taxes are an expense and whether the required method of accounting for deferred taxes is helpful in assessing future cash flows are still not resolved. This paper argues that the simultaneous use of incompatible unit perspectives by the FASB in S109 is the basis of the disagreements most critics have with the FASB's positions. The FASB adopted both individual and aggregate event perspectives, thus arguing both sides of the coin simultaneously and drawing insupportable conclusions regarding the recognition of liabilities and assets. This study concludes that the taxation of a corporation is an aggregate phenomenon and an aggregate perspective is required.

The flow-through method of accounting for taxes results in significant decreases in the debt-to-equity ratio for most firms, improving their financial position. The flow-through method represents a logical approach in accounting for taxes as long as taxation is viewed as a transaction occurring between the private and public sectors. That is, taxation is the act of transferring a portion of the periodic increase in an entity=s net worth (computed using the tax law) to a government entity for the privilege of conducting business in that government=s jurisdiction. This method results in the tax provision for a period equaling the required cash outflow for taxes for that period, and the 
Table 4 - Changes In Deferred Taxes From Year To Year (Persisting Firms)

\begin{tabular}{lcccc}
\hline $\begin{array}{c}\text { Years } \\
\text { Of } \\
\text { Comparison }\end{array}$ & $\begin{array}{c}\text { Number of } \\
\text { Firms with } \\
\text { Increases }\end{array}$ & $\begin{array}{c}\text { Number of } \\
\text { Firms with } \\
\text { Decreases }\end{array}$ & $\begin{array}{c}\text { Number of } \\
\text { Firms with } \\
\text { No Change }\end{array}$ & $\begin{array}{c}\text { Total } \\
\text { Number } \\
\text { of Firms }\end{array}$ \\
$2002-2001$ & 356 & 349 & 112 & 817 \\
$2001-2000$ & 347 & 265 & 205 & 817 \\
$2000-1999$ & 378 & 246 & 193 & 817 \\
$1999-1998$ & 376 & 235 & 206 & 817 \\
$1998-1997$ & 377 & 244 & 196 & 817 \\
$1997-1996$ & 397 & 233 & 187 & 817 \\
$1996-1995$ & 393 & 247 & 177 & 817 \\
$1995-1994$ & 405 & 238 & 174 & 817 \\
$1994-1993$ & 389 & 262 & 166 & 817 \\
$1993-1992$ & 375 & 307 & 135 & 817 \\
$1992-1991$ & 368 & 330 & 119 & 817 \\
$1991-1990$ & 356 & 354 & 107 & 817 \\
$1990-1989$ & 419 & 303 & 95 & 817 \\
$1989-1988$ & 459 & 275 & 83 & 817 \\
$1988-1987$ & 471 & 211 & 67 & 817 \\
$1987-1986$ & 548 & 198 & 58 & 817 \\
$1986-1985$ & 580 & 190 & 39 & 817 \\
$1985-1984$ & 608 & 211 & 19 & 817 \\
$1984-1983$ & 601 & & 5 & \\
\hline
\end{tabular}

The data underlying the empirical tests are available from the COMPUSTAT. Readers with comments or questions are encouraged to contact the authors via e-mail.

\section{References}

1. Accounting Principles Board. Opinion No. 11: Accounting For Income Taxes. New York, NY: AICPA, 1967.

2. Bierman, Harold, Jr., "One More Reason to Revise Statement No. 96," Accounting Horizons (July 1990), pp. 42-46.

3. Burton, John C., and Robert J. Sack, "Tax Allocation: Time for a Fundamental Change," Accounting Horizons (July 1989), pp. 110-112.

4. Devine, Carl T., "The Unit Problem," Essays in Accounting Theory, Volume II. Sarasota, FL: American Accounting Association, 1985.

5. Financial Accounting Standards Board. SFAC 6: Elements of Financial Statements. Norwalk, CT: FASB, 1985.

6. Financial Accounting Standards Board. FAS 96 - Accounting for Income Taxes. Norwalk, CT: FASB, 1987.

7. Financial Accounting Standards Board. FAS 108: Accounting for Income Taxes - Deferral of the Effective Date of FASB Statement No.96. Norwalk, CT: FASB, 1991. Financial Accounting Standards Board. FAS 109 - Accounting for Income Taxes. Norwalk, CT: FASB, 1992.

8. Gregory, George J., Thomas R. Petree, and Randall J. Vitray, "FASB 109: Planning for Implementation and Beyond," Journal of Accountancy (June 1992), pp. 44-50.

9. Jeter, Debra C., and Paul K. Chancy, "A Financial Statement Analysis Approach to Deferred Taxes," Accounting Horizons (December 1988), pp. 41-49.

10. Magee, Robert W., Accounting for Income Taxes. Montvale, NJ: Institute of Management Accountants, 1984.Parks, 
11. James T., "A Guide to FASB's Overhaul of Income Tax Accounting," Journal of Accountancy (April 1988), pp. 24-34.

12. Rayburn, Frank R., "Discounting of Deferred Income Taxes: An Argument for Reconsideration," Accounting Horizons (March 1987), pp. 43-49. Schroeder,

13. Richard G., Myrtle Clark, and Jack Cathey. Financial Accounting Theory and Analysis, $7^{\text {th }}$ ed. New York, NY: John Wiley and Sons, 2001.

14. Wolk, Harry I., Dale R. Martin, and Virginia A. Nichols, "Statement of Financial Accounting Standards No. 96: Some Theoretical Problems," Accounting Horizons (July 1989), pp. 1-5.

Notes 